\title{
EVALUASI PROGRAM MUTU BERBASIS SEKOLAH (MMBS) DI SMA N 61 UNGGULAN JAKARTA TIMUR (PENDEKATAN EVALUASI BERDASARKAN MODEL CIPP)
}

\author{
Supadi \\ e-mail: supadi_mpd@yahoo.com \\ Manajemen Pendidikan Universitas Negeri Jakarta
}

Jl. Rawamangun Muka, Jakarta 13220

\begin{abstract}
Abstrak: Salah satu hal yang menyebabkan keberhasilan dan keefektifan lembaga sekolah dikarenakan mutu pencapaian hasil belajar siswanya. Pencapaian hasil belajar siswa tergantung pada keberhasilan guru dalam membantu siswa untuk mencapai hasil belajarnya. Tujuan penelitian ini adalah mengevaluasi program pembelajaran meliputi komponen input, proses, dan output proses pembelajaran di SMA 61 Jakarta. Metode yang digunakan adalah metode kualitatif. Penelitian dilakukan selama tahun 2014. Teknik analisis data yang digunakan menggunakan model interaktif yang meliputi reduksi data, penyajian data, dan penarikan kesimpulan. Hasil penelitian berupa evaluasi program mutu yang dilakukan di SMA 61 Jakarta berkaitan dengan komponen input, proses, dan output. Kombinasi ketiga komponen, input, proses, dan kualitas produk merupakan faktor penentu untuk meningkatkan kualitas pendidikan. Penelitian ini menemukan partisipasi komite sekolah dalam penyelenggaraan pendidikan di SMAN 61 Jakarta belum optimal. Oleh karena itu, diharapkan komite sekolah mampu secara optimal tidak hanya memobilisasi pembiayaan pendidikan dari masyarakat.
\end{abstract}

Kata-kata kunci: manajemen mutu berbasis sekolah, evaluasi program, CIPP

\section{EVALUATION OF QUALITY BASED SCHOOL PROGRAM (MMBS) IN SMA N 61 EAST JAKARTA (EVALUATION APPROACH BASED ON CIPP MODEL)}

\begin{abstract}
One of the things that lead to the success and effectiveness of school institutions is due to the quality of student achievement. Achievement of student learning outcomes depends on the success of teachers in helping students to achieve learning outcomes. The purpose of this research is to evaluate the learning program covering input component, process, and output of learning process in SMA 61 Jakarta. The method used is a qualitative method. The study was conducted during 2014. Data analysis techniques used using interactive models that include data reduction, data presentation, and conclusions. The results of the evaluation of the quality program conducted in SMA 61 Jakarta related to input, process and output components. The combination of the three elements, inputs, processes, and product quality is the determining factor to improve the quality of education. This study found the participation of school committees in the implementation of education at SMAN 61 Jakarta is not optimal. Therefore, it is expected that school committees can optimally not only mobilize education funding from the community.
\end{abstract}

Keywords: school-based quality management, program evaluation, CIPP

\section{PENDAHULUAN}

Sejalan dengan implementasi otonomi daerah dengan asas desentralisasi, peningkatan kualitas pendidikan menuntut partisipasi dan pemberdayaan seluruh komponen pendidikan dan penerapan konsep pendidikan sebagai suatu sistem. Pendekatan peningkatan mutu pendidikan yang sesuai dengan paradigma dan gagasan tersebut adalah penerapan manajemen berbasis sekolah. Sejak tahun 1999, konsep MBS telah diujicobakan di sekolah-sekolah di Indonesia.

MBS dimaknai sebagai pengorganisasian dan penyerasian sumber daya secara mandiri oleh sekolah melalui sejumlah input manajemen untuk mencapai tujuan sekolah dalam kerangka pendidikan nasional dengan melibatkan semua kelompok kepentingan yang terkait secara langsung dalam proses pengambilan keputusan. Secara ringkas, MBS adalah otonomi manajemen sekolah dalam pengambilan keputusan partisipatif (Nurkholis, 2003: 8). Depdiknas menyebut MBS dengan Manajemen 
Peningkatan Mutu Berbasis Sekolah. Secara umum, MPMBS adalah model manajemen yang memberikan otonomi lebih luas pada sekolah dan mendorong pengambilan keputusan partisipatif, melibatkan secara langsung semua warga sekolah untuk meningkatkan mutu sekolah berdasarkan kebijakan pendidikan nasional (Departemen Pendidikan Nasional, 2002: 3).

Pengertian mutu dapat dilihat berdasarkan konsep secara absolut dan relatif. Dalam konsep absolut, sesuatu (barang) disebut berkualitas bila memenuhi standar tertinggi dan sempurna. Bila diterapkan dalam pendidikan, konsep mutu absolut ini bersifat elitis. Dalam konsep relatif, mutu berarti memenuhi spesifikasi yang ditetapkan dan sesuai dengan tujuan (fit for their purpose). Mutu dalam konsep relatif berhubungan dengan produsen, maka mutu berarti sesuai dengan spesifikasi yang ditetapkan pelanggan. Sekolah yang bermutu memiliki kriteria: fokus pada pelanggan, pencegahan masalah, investasi sumber daya, memiliki strategi mutu, mendefinisikan karakteristik mutu pada seluruh area organisasi, memiliki kebijakan dan rencana mutu, proses perbaikan mutu melibatkan semua orang, memiliki fasilitator mutu, memiliki aturan dan tanggung jawab yang jelas, memiliki strategi evaluasi yang jelas, melihat mutu sebagai cara untuk meningkatkan kepuasan pelanggan (Sallis, 2010: 163-164).

Mutu pendidikan mengacu pada input, proses, luaran, dan dampaknya. Mutu input dapat dilihat dari beberapa sisi. Pertama, kondisi baik atau tidaknya masukan sumber daya manusia, misalnya kepala sekolah, guru, laboran, staf tata usaha, dan peserta didik. Kedua, memenuhi atau tidaknya kriteria masukan material berupa alat peraga, buku-buku, kurikulum, prasarana, sarana sekolah, dan lain-lain. Ketiga, memenuhi atau tidaknya kriteria masukan berupa perangkat lunak, misalnya peraturan, struktur organisasi. Keempat, mutu masukan yang bersifat harapan misalnya visi, misi, motivasi, ketekunan, dan cita-cita. Mutu proses mengandung makna kemampuan sumber daya sekolah mentransformasikan multi jenis masukan dan situasi untuk mencapai derajat nilai tambah tertentu dari peserta didik (Danim, 2008: 53).

Dalam pendekatan fungsi produksi, mutu pendidikan ditentukan oleh faktor input dan faktor proses. Faktor input diantaranya adalah peserta didik, kurikulum, bahan ajar, metode pembelajaran, sarana pembelajaran di sekolah, serta dukungan administrasi dan prasarana sekolah. Faktor proses diantaranya adalah penciptaan suasana yang kondusif, koordinasi proses pembelajaran, dan juga interaksi antar unsurunsur di sekolah, baik guru dengan guru, peserta didik dengan peserta didik, maupun guru dan staf administrasi sekolah. Konteks mutu dapat pula dilihat dari prestasi yang dicapai sekolah. Prestasi ini dapat dilihat dari student achievement dalam bidang akademik maupun nonakademik. Di Indonesia, prestasi akademik umumnya dijadikan salah satu indikator mutu sekolah yang paling dominan, termasuk prestasi siswa dalam Ujian Nasional (UN).

Hasil penelitian Doyle sebagaimana dikutip Jaedun (2011:5) menyatakan bahwa salah satu indikator dari keberhasilan atau keefektifan sekolah adalah mutu pencapaian hasil belajar siswanya, dan hasil belajar siswa tersebut akan sangat tergantung pada sejauhmana keberhasilan guru dalam membantu siswa untuk mencapai hasil belajarnya. Oleh karena itu, guru mempunyai peran yang sangat menentukan bagi keberhasilan pendidikan di sekolah.

Berdasarkan hasil penelitian Suryana (2011:5), salah satu sebab rendahnya mutu pendidikan adalah belum efektifnya proses pembelajaran. Proses pembelajaran selama ini masih terlalu berorientasi terhadap penguasaan teori dan hafalan dalam semua bidang studi yang menyebabkan kemampuan belajar peserta didik menjadi terhambat. Metode pembelajaran yang terlalu berorientasi pada guru (teacher oriented) sehingga proses pembelajaran yang menyenangkan, mengasyikkan, dan mencerdaskan menjadi kurang optimal. Satu diantara faktor yang menyebabkan kurang efektifnya proses pembelajaran adalah kualifikasi pendidikan guru. Untuk jenjang pendidikan SMP dan SMA/SMK, banyak terjadi ketidaksesuaian antara pelajaran yang diajarkan dengan kualifikasi guru. Pada jenjang SMP, SMA dan SMK persentase guru yang belum memiliki kualifikasi sesuai dengan latar belakang pendidikan masingmasing adalah $36 \%$, 33\%, dan $43 \%$.

Berdasarkan pemaparan dan sajian data di atas, permasalahan penelitiannya adalah bagaimanakah implementasi MMBS selama ini di sekolah? Apakah implementasi MMBS berdampak pada peningkatan mutu output pendidikan di sekolah? Untuk menjawab permasalahan tersebut, maka penelitian terhadap pelaksanaan MBS dilakukan di SMAN 61 Jakarta yang berstatus sekolah unggulan. Penelitian bertujuan mengkaji dukungan komponen konteks, input, dan proses dalam pendidikan merupakan implementasi MMBS, serta komponen output pendidikan sebagai hasil implementasi MMBS di SMAN 61 Jakarta. 


\section{METODE PENELITIAN}

Penelitian menggunakan pendekatan kualitatif. Penelitian kualitatif secara inheren merupakan fokus perhatian dengan beragam metode. Penggunaan metode yang beragam atau triangulasi mencerminkan upaya untuk memperoleh pemahaman yang mendalam mengenai suatu fenomena yang sedang dikaji.

Untuk memperoleh data penelitian secara lengkap dilakukan dengan berbagai teknik pengumpulan data. Pertama, wawancara dengan informan kunci yang bertindak sebagai manajer pendidikan pada tingkat satuan pendidikan yaitu kepala sekolah dan selanjutnya pemilihan informan lainnya diperoleh dengan teknik snowball. Kedua, kajian dokumen. Kajian dilakukan terhadap dokumendokumen yang terkait dengan Rencana Kegiatan dan Anggaran Sekolah (RKAS), rencana peningkatan mutu sekolah, visi misi sekolah, perencanaan pembelajaran, dan keputusan kepala SMAN 61 Jakarta. Ketiga, observasi terhadap objek-objek yang dapat memperkuat data yang diperoleh sebelumnya dan yang dapat memperjelas pemahaman atas proses dan hasil pelaksanaan program MMBS di SMAN 61 Jakarta. Keempat, kuesioner diberikan kepada guru dan karyawan sebagai pihak yang terlibat secara langsung dalam penerapan MMBS untuk mengetahui dan mengecek persepsi responden terhadap objek penelitian.

Analisis data dilakukan secara interaktif dan berlangsung terus menerus selama proses penelitian. Model interaktif dengan menerapkan tiga alur kegiatan secara bersamaan, yaitu reduksi data, penyajian data, dan penarikan kesimpulan.

\section{HASIL DAN PEMBAHASAN}

\section{Hasil}

Komite sekolah berpartisipasi secara terbatas dalam penyusunan Rencana Kegiatan dan Anggaran Sekolah (RKAS). Komite sekolah lebih dominan dalam menggalang partisipasi dan memobilisasi pembiayaan pendidikan dari orang tua peserta didik. Komite sekolah tersubordinasi dari struktur pengambilan keputusan sekolah. Pengambilan keputusan hanya melibatkan kepala sekolah, wakasek, guru, staf, dan tim pengembang.

Komponen input pendidikan di SMAN 61 Jakarta memiliki kesiapan tinggi dalam pelaksanaan MMBS. Pemahaman warga sekolah terhadap visi, misi sekolah merupakan modal yang berharga dalam pelaksanaan proses pendidikan. Kondisi tersebut

dapat menumbuhkan semangat kebersamaan dan menyatukan seluruh warga sekolah dalam pelaksanaan program pendidikan. Aspek yang belum sesuai dengan kriteria evaluasi adalah ketersediaan $30 \%$ guru yang berkualifikasi pendidikan S2.

Output pendidikan SMAN 61 Jakarta termasuk bermutu. Mutu output pendidikan dipengaruhi oleh raw input yang juga bermutu. Input yang bermutu yang dikelola dalam sebuah proses pendidikan yang juga bermutu akan menghasilkan produk yang bermutu pula. Sistem mutu pendidikan di SMAN 61 Jakarta terbentuk atas sub-sub sistem mutu yang dirancang dan dikendalikan dengan sasaran mutu yang menjadi landasan dalam penyelenggaraan pendidikan. Hasil penelitian dijabarkan dalam tabel berikut:

Tabel 1

Hasil Temuan Konteks, Input, Proses, dan Produk

\begin{tabular}{|c|c|c|c|}
\hline Komponen & Aspek & Indikator Ideal & Hasil Temuan \\
\hline \multirow[t]{3}{*}{ Konteks } & $\begin{array}{l}\text { Peran komite } \\
\text { sekolah dalam } \\
\text { implementasi } \\
\text { MMBS }\end{array}$ & $\begin{array}{l}\text { 1. Memberi masukan } \\
\text { 2. Pengesahan RKAS } \\
\text { 3. Partisipasi aktif dalam } \\
\text { peningkatan mutu } \\
\text { 4. Peningkatan kualitas } \\
\text { layanan }\end{array}$ & $\begin{array}{l}\text { Dari empat indikator } \\
\text { yang ada, baru } \\
2 \text { indikator yang } \\
\text { terpenuhi yaitu } \\
\text { memberimasukandan } \\
\text { pengesahan RKAS. }\end{array}$ \\
\hline & $\begin{array}{l}\text { Kurikulum } \\
\text { dan program } \\
\text { pengajaran }\end{array}$ & $\begin{array}{l}\text { 1. Kurikulum nasional } \\
\text { dan adaptasi kurikulum } \\
\text { dari negara OECD } \\
\text { 2. Terdapat kurikulum } \\
\text { pengayaan } \\
\text { 3. Penyusunan RPP } \\
\text { sebelum memasuki tahun } \\
\text { ajaran baru }\end{array}$ & $\begin{array}{l}\text { Tiga indikator yang } \\
\text { sudah ada terpenuhi } \\
\text { yaitu kurikulum } \\
\text { nasional di adaptasi } \\
\text { dari negara OECD, } \\
\text { terdapat kurikulum } \\
\text { prnga y a an, dan } \\
\text { penyusunan RPP rutin } \\
\text { sebelum memasuki } \\
\text { tahun ajaran baru. }\end{array}$ \\
\hline & Visi dan Misi & $\begin{array}{l}\text { Visi misi organisasi harus } \\
\text { disebarluaskan pada } \\
\text { seluruh anggota organisasi } \\
\text { sehingga mereka memiliki } \\
\text { pemahaman dan perilaku } \\
\text { y a ng sa ma untuk } \\
\text { mewujudkan visi misi } \\
\text { tersebut. }\end{array}$ & $\begin{array}{l}\text { 1. Terdapat visi, misi } \\
\text { sekolah,dicantumkan } \\
\text { dalam panduan, } \\
\text { buku profile sekolah } \\
\text { dan buku rangkuman } \\
\text { hasil rapat kerja } \\
\text { 2. Visi misi dipasang } \\
\text { di tempat-tempat } \\
\text { strategis } \\
\text { 3. Warga sekolah } \\
\text { memahami visi misi } \\
\text { dan sekolah }\end{array}$ \\
\hline \multirow{2}{*}{ Input } & $\begin{array}{l}\mathrm{T} \text { e } \mathrm{n} \mathrm{a} g \text { a } \\
\text { pendidik dan } \\
\text { kependidikan }\end{array}$ & $\begin{array}{l}\text { Manajemen tenaga } \\
\text { pe nd idik d a n } \\
\text { kependidikan dilakukan } \\
\text { untuk mendayagunakan } \\
\text { tenaga kependidikan } \\
\text { secara efektif dan efisien } \\
\text { untukmencapai hasilyang } \\
\text { optimal. }\end{array}$ & $\begin{array}{l}\text { 1. Guru berjumlah } \\
56 \text { orang, } 46 \\
\text { berkualifikasi S1, } 10 \\
\text { orang S2. } \\
\text { 2. Peningkatan } \\
\text { kompetensi tenaga } \\
\text { pendidik dan } \\
\text { kependidikan melalui } \\
\text { seminar, workshop, } \\
\text { IHT. }\end{array}$ \\
\hline & Peserta didik & $\begin{array}{l}\text { Manajemen kesiswaan } \\
\text { dilakukan dengan } \\
\text { menerapkan berbagai } \\
\text { program layanan } \\
\text { untuk membantu siswa } \\
\text { mengembangkan minat, } \\
\text { bakatdan kemampuannya } \\
\text { serta untuk mengatasi } \\
\text { permasalahan yang } \\
\text { dihadapi siswa terutama } \\
\text { berkaitan dengan hasil } \\
\text { belajar siswa. }\end{array}$ & $\begin{array}{l}\text { 1. Nilai terendah calon } \\
\text { peserta didik baru } \\
76,73 \text { tertinggi } 94,48 \text {, } \\
\text { NEM input terendah } \\
\text { TA } 2011 / 2012 \text { untuk } 4 \\
\text { mata pelajaran } 31,00 \text {, } \\
\text { tertinggi } 38,80 \text {, rata- } \\
\text { rata } 36,42 \text {. } \\
\text { 2. Mengembangkan } \\
\text { manajemen } \\
\text { pembinaan peserta } \\
\text { didik: program } \\
\text { remedial, pengayaan, } \\
\text { BK, LDKS. } \\
\text { 3. Terdapat campur } \\
\text { tangan dinas } \\
\text { pendidikan dalam } \\
\text { PPDB. }\end{array}$ \\
\hline
\end{tabular}




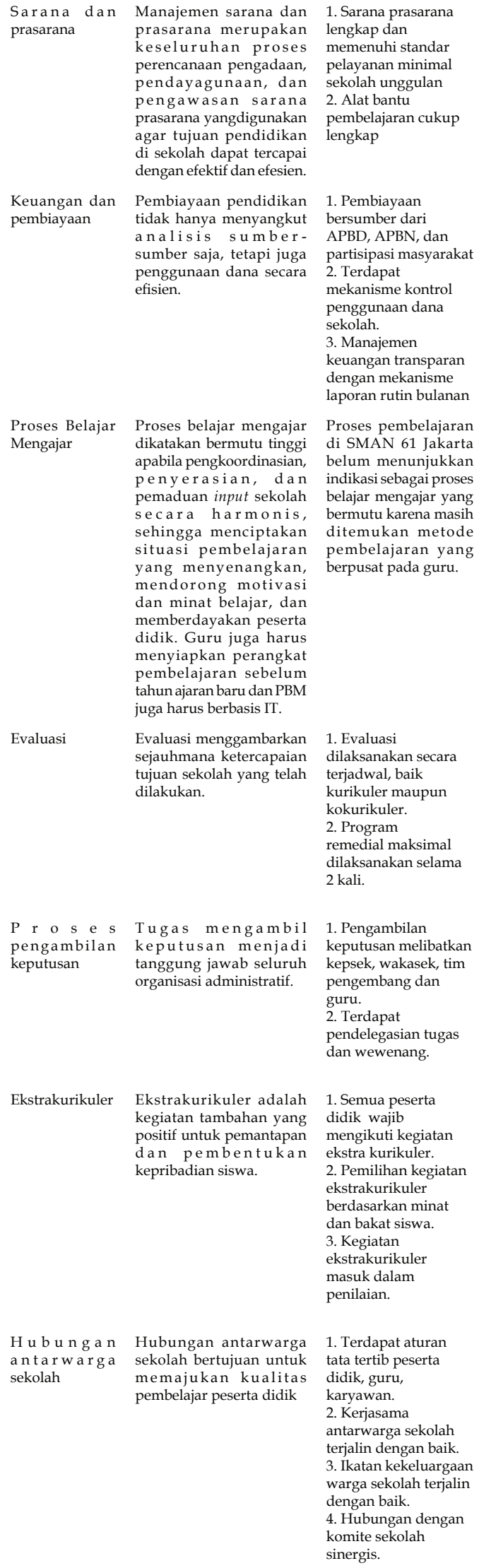

\begin{tabular}{|c|c|c|c|}
\hline & $\begin{array}{l}\text { Prestasi peserta } \\
\text { didik }\end{array}$ & & $\begin{array}{l}\text { 1. Rata-rata nilai } \\
\text { ujian nasi onal IPA } \\
8,48 \text {, IPS } 8,35 \text {. } \\
\text { 2. Rata-rata peserta } \\
\text { didik yang diterima di } \\
\text { PTN }>90 \% \text {. } \\
\text { 3. Siswa banyak } \\
\text { meraih prestasi dalam } \\
\text { lomba di bidang } \\
\text { akademis dan non- } \\
\text { akademik. } \\
\text { 4. Tidak terdapat } \\
\text { peserta didik yang } \\
\text { terlibat kasus narkoba } \\
\text { dan tawuran }\end{array}$ \\
\hline Produk & $\begin{array}{l}\text { Prestasi Guru } \\
\text { dan Kepsek }\end{array}$ & $\begin{array}{l}\text { Mutu pendidikan ditandai } \\
\text { juga dengan prestasi } \\
\text { akademik maupun non } \\
\text { akademik yang diraih oleh } \\
\text { peserta didik dan tenaga } \\
\text { pendidik. }\end{array}$ & $\begin{array}{l}\text { 1. Terdapat guru yang } \\
\text { meraih juara lomba } \\
\text { guru teladan dan } \\
\text { lomba bahasa Inggris. } \\
\text { 2. Kepala sekolah } \\
\text { menjadi ketua ketua } \\
\text { forum RSBI tingkat } \\
\text { provinsi dan ketua } \\
\text { MKKS provinsi }\end{array}$ \\
\hline & Prestasi Sekolah & & $\begin{array}{l}\text { 1. Tingkat kelulusan } \\
100 \% \\
2 . \text { Sekolah } \\
\text { mendapatkan } \\
\text { penghargaan dalam } \\
\text { lomba kebersihan } \\
\text { lingkungan (adipura) }\end{array}$ \\
\hline
\end{tabular}

\section{Pembahasan}

Implementasi MMBS di SMAN 61 Jakarta belum sejalan dengan konsep MMBS, karena tidak melibatkan semua warga sekolah dalam keseluruhan proses pengambilan keputusan. Padahal, hakikat MBS adalah otonomi sekolah dan mendorong pengambilan keputusan secara partisipatif dengan melibatkan semua warga sekolah untuk meningkatkan mutu sekolah (Nurkholis, 2003: 8). Pengambilan keputusan di SMAN 61 Jakarta hanya melibatkan kepala sekolah, wakil kepala sekolah, guru senior, kepala tata usaha, dan tim pengembang, serta tidak melibatkan komite sekolah sebagai representasi kepentingan masyarakat. Ditegaskan oleh Raynolds (2005: 121) bahwa komite sekolah berperan dalam peningkatan mutu melalui partisipasi aktif dalam penyelenggaraan pendidikan untuk lebih meningkatkan kualitas keputusan dalam program pembelajaran dan layanan sekolah, efektivitas program dan layanan program, dan kesuksesan siswa.

Komite sekolah hanya dilibatkan dalam pengesahan RKAS yang disusun oleh sekolah. Pelibatan ini terutama berkaitan dengan dukungan dan partisipasi komite sekolah dalam memobilisasi sumbangan pendidikan dari orang tua siswa. Hasil kajian komponen konteks pendidikan berupa partisipasi dan dukungan komite sekolah dalam penyelenggaraan pendidikan di SMA Negeri 61 
Jakarta, memiliki kemiripan dengan hasil penelitian yang dilakukan di Kabupaten Sleman Provinsi Daerah Istimewa Yogyakarta. Berdasarkan hasil studi empirik terkait proses pengambilan keputusan di SMP Negeri yang berstandar internasional, komite sekolah hanya memberikan masukan terbatas pada dukungan program yang sudah dirancang secara profesional oleh kepala sekolah dan guru (Dwiningrum, 2011: 106).

Kurikulum yang digunakan di SMA Negeri 61 Jakarta adalah kurikulum nasional (KTSP) yang diperkaya dengan kurikulum dari negara OECD. Perpaduan kurikulum nasional dan hasil adopsi dari kurikulum di negara-negara maju kemudian disebut dengan Kurikulum SMAN 61. Adaptasi kurikulum tersebut dilakukan berdasarkan identifikasi kebutuhan kompetensi yang harus dimiliki oleh siswa SMAN 61 Jakarta. Dengan perspektif interdisiplin dan pendekatan reflektif, terpadu dan holistik, negaranegara maju yang tergabung dalam OECD membentuk sebuah fondasi internasional untuk memformulasikan kompetensi kunci. Ada tiga kategori kompetensi kunci yang berhasil diidentifikasi, yaitu (1) kemampuan bertindak secara otonom; (2) menggunakan alat secara interaktif; (3) memfungsikan diri dalam kelompokkelompok yang secara sosial heterogen (Rivai dan Murni, 2009: 192).

Sebagai sekolah yang berstatus unggulan, manajemen SMAN 61 Jakarta mengembangkan program sosialisasi visi misi sekolah kepada seluruh warga sekolah. Sosialisasi tersebut dilakukan dengan berbagai cara, yaitu menempelkan visi misi di majalah dinding sekolah, di tempat-tempat strategis, di dalam buku panduan, buku profil sekolah dan buku hasil kegiatan rapat kerja. Hal ini sejalan dengan pendapat Bryson, bahwa visi organisasi harus disebarluaskan pada seluruh anggota organisasi sehingga mereka memiliki pemahaman dan perilaku yang sama untuk mewujudkan visi tersebut. Bryson (2004: 226) mengatakan, "The vision statement should be widely circulated among organizational members and other key stakeholders after appropriate consultations, review, and sigh-offs. A vision of success can have little effect if organizational members are kept in the dark about it".

Manajemen tenaga kependidikan dilakukan untuk mendayagunakan tenaga kependidikan secara efektif dan efisien untuk mencapai hasil yang optimal. Salah satu aspek dalam manajemen tenaga kependidikan di SMAN 61 Jakarta adalah fungsi pengembangan tenaga kependidikan dalam rangka peningkatan pengetahuan, keterampilan dan sikap. Fungsi pengembangan tenaga kependidikan dilaksanakan dengan berbagai bentuk kegiatan, seperti seminar workshop, diklat, dan IHT.

Manajemen kesiswaan adalah penataan dan pengaturan kegiatan yang berkaitan dengan peserta didik, mulai masuk sampai keluarnya peserta didik dari suatu sekolah (Mulyasa, 2011: 46). Manajemen kesiswaan di SMAN 61 Jakarta untuk mengelola beragam perbedaan dan stereotipe siswa adalah memberikan perlakuan yang sama pada seluruh siswa. Manajemen kesiswaan dilakukan dengan menerapkan berbagai program layanan untuk membantu siswa mengembangkan minat, bakat dan kemampuannya serta untuk mengatasi permasalahan yang dihadapi siswa terutama berkaitan dengan hasil belajar siswa.

Manajemen sarana prasarana diterapkan dengan menempatkan tenaga kependidikan yang bertanggung jawab terhadap optimalisasi fungsi dan pemanfaatan sarana prasarana pendidikan. Manajemen sarana dan prasarana merupakan keseluruhan proses perencanaan pengadaan, pendayagunaan, dan pengawasan sarana prasarana yang digunakan agar tujuan pendidikan di sekolah dapat tercapai dengan efektif dan efisien (Rohiat, 2010: 26). Sarana dan prasarana pendidikan di SMAN 61 Jakarta cukup memadai dilihat dari kuantitas dan kualitasnya dalam mendukung kelancaran proses pembelajaran

Standar pelaporan keuangan ditetapkan dengan kriteria ketepatan laporan pe rutin bulanan disampaikan paling lambat tanggal 15 setiap bulannya. Laporan keuangan komite SMA Negeri 61 Jakarta untuk tahun 2011/2012 telah diaudit selama 5 tahun berturut-turut oleh Kantor Akuntan Publik (KAP) independen dengan mendapat penilaian Wajar Tanpa Pengecualian (WTP). Struktur keuangan sekolah belum tentu sekuat program yang akan dikembangkan. Oleh sebab itulah, sekolah diberi kewenangan untuk berkomunikasi dengan stakeholder-nya bukan untuk menarik berbagai retribusi tambahan dari mereka, tetapi untuk membahas program-program yang rasional untuk dikembangkan serta strategi fundrising yang dapat dikembangkan untuk mendukung struktur keuangan sekolah (Rosyada, 2007: 254-255).

Dalam MBS, proses belajar memiliki tingkat kepentingan tertinggi daripada proses lainnya. Proses dikatakan bermutu tinggi apabila pengkoordinasian, penyerasian, dan pemaduan input sekolah secara harmonis, sehingga menciptakan situasi pembelajaran yang menyenangkan, mendorong motivasi dan minat belajar, dan memberdayakan peserta didik (Departemen Pendidikan Nasional, 2002: 7). Jika mengacu pada konsep tersebut, maka proses pembelajaran diSMAN 61 Jakarta belum menunjukkan indikasi sebagai proses belajar mengajar yang 
bermutu. Kondisi ini disebabkan karena metodologi pembelajaran yang diterapkan lebih berpusat pada guru (teacher centered) dan bukan pada siswa (student centered), monoton, dan kurang variatif.

Realitas tersebut memiliki kesamaan dengan hasil penelitian Suryana (2011: 10), bahwa salah satu sebab rendahnya mutu pendidikan adalah belum efektifnya proses pembelajaran. Proses pembelajaran masih berorientasi terhadap penguasaan teori dan hafalan dengan metode pembelajaran yang terlalu berorientasi pada guru (teacher oriented). Kenyataan ini terungkap melalui data yang diperoleh dari beberapa narasumber, bahwa ketika proses belajar dan pembelajaran berlangsung kondisi suasana kelas sangat sepi. Data tersebut dapat dimaknai, bahwa tidak terjadi dialog yang dinamis antara guru dan siswa dalam proses pembelajaran.

Keberhasilan MBS ditentukan oleh keberhasilan manajemen sekolah dalam mengelola tenaga kependidikan. Guru harus mampu merancang, memilih bahan pelajaran, dan strategi pembelajaran yang sesuai dengan latar belakang anak yang berbeda, mengelola proses pembelajaran secara taktis dan menyenangkan, mampu memilih media belajar, dan merancang program evaluasi yang sesuai dengan tujuan pendidikan yang berorientasi pada penguasaan kompetensi (Soedijarto, 2008: 191).

Peran guru dalam mengembangkan strategi pembelajaran sangat penting karena aktivitas siswa sangat dipengaruhi oleh sikap dan perilaku guru dalam kelas. Jika guru antusias, memperhatikan kebutuhan-kebutuhan siswa, maka siswa pun akan mengembangkan aktivitas belajarnya dengan baik dan antusias (Rosyada, 2007: 121).

Konsep belajar tuntas menghendaki penguasaan siswa minimal $80 \%$ dari target kurikuler atau batasbatas minimal tertentu lainnya. Indeks tersebut hanya dapat diketahui jika guru melakukan tes setiap akhir dari proses pembelajaran dengan menggunakan instrumen tes yang baik dan benar. Jika tidak dilakukan tes, guru tidak akan mengetahui indeks penguasaan siswa terhadap pelajaran yang dipelajari. Atau jika tes dilakukan dengan instrumen yang buruk, maka hasilnya tidak akan mampu menggambarkan kenyataan sebenarnya.

Dari hasil evaluasi kemudian ada umpan balik kepada guru dan siswa. Umpan balik bertujuan memberikan reinforcement kepada siswa, sehingga pihak sekolah dapat menentukan kegiatan tindak lanjut. Evaluasi juga harus menjadi proses yang berkelanjutan. Hasil evaluasi harus dibicarakan dengan siswa, untuk melengkapi hasil evaluasi. Sikap melibatkan seluruh elemen akan sangat membantu dalam membangun kecakapan analitis para pelajar (Sallis, 2010: 88).

Salah satu kunci keberhasilan sekolah adalah kemampuan kepala sekolah dalam mendistribusikan tugas-tugas yang terkait dengan proses pendidikan dan pembelajaran kepada guru dan staf, dan proses pengambilan keputusan-keputusan penting sekolah. Dalam perspektif Robbins dan Timothi A. Judge, organizational need strong leadership and strong management for optimal effectiveness (Robbins dan Judge, 2011: 410).

Untuk menciptakan iklim sekolah yang kondusif bagi berlangsungnya proses pendidikan, manajemen SMA Negeri 61 Jakarta menjalin hubungan dengan seluruh stakeholders pendidikan. Hal ini sesuai dengan karakteristik MBS, yaitu pelibatan stakeholder lokal dalam pengambilan keputusan di sekolah dalam MBS dapat meningkatkan lingkungan belajar yang efektif bagi siswa (Nurkholis, 2003: 3). MBS merupakan inovasi dalam manajemen pendidikan yang menekankan pada process-oriented dalam suatu siklus perbaikan dan peningkatan mutu yang berkelanjutan dalam rangka memperbaiki kualitas pendidikan terutama memperbaiki lingkungan pengajaran dan pembelajaran bagi siswa.

Mutu output pendidikan ditandai dengan prestasi akademik siswa kaitannya dengan pencapaian nilai ujian nasional menunjukkan hasil yang cukup memuaskan, persentase daya serap ke PTN, lebih dari $90 \%$. Sekolah harus memiliki output yang diharapkan. Output sekolah adalah prestasi sekolah yang dihasilkan oleh proses pembelajaran dan manajemen di sekolah. Output berupa prestasi akademik (academic achievement) misalnya NEM, lomba karya ilmiah remaja, lomba bahasa Inggris, matematika, dan fisika (Departemen Pendidikan Nasional, 2002: 14).

\section{PENUTUP}

\section{Kesimpulan}

Secara umum, pelaksanaan Manajemen Mutu Berbasis Sekolah di SMA N 61 Jakarta dapat dijelaskan sebagai berikut (1) partisipasi komite sekolah dalam penyelenggaraan pendidikan di SMAN 61 Jakarta belum optimal. Partisipasi komite sekolah lebih dominan dalam memobilisasi pembiayaan pendidikan dari masyarakat; (2) komponen input pendidikan memiliki tingkat kesiapan tinggi dalam implementasi MMBS. Indikator-indikator mutu input antara lain: (a) memiliki kebijakan, tujuan dan sasaran mutu yang jelas; (b) mutu input sumber daya; serta (c) input manajemen yang memadai berupa rencana dan 
program kerja, serta peraturan-peraturan sekolah; (3) komponen proses pendidikan termasuk kategori baik. Aspek yang masih perlu mendapat perhatian adalah penggunaan metode pembelajaran. Metode pembelajaran kurang variatif dan lebih berpusat pada guru; dan (4) output pendidikan termasuk dalam kategori baik. Ini terlihat dari mutu komponen output pendidikan SMA Negeri 61 Jakarta yang merupakan hasil dari proses pembelajaran dan manajemen mutu yang diterapkan di atas rata-rata standar yang diterapkan sekolah. Mutu output pendidikan terdiri atas academic achievement dan non-academic achievement.

\section{DAFTAR PUSTAKA}

Bryson, J.M. (2004). Strategic planning for public and nonprofit organizational. San Fransisco: John Wiley and Sons, Inc.

Danim, S. (2008). Visi baru manajemen sekolah: Dari unit birokrasi ke lembaga akademik. Jakarta: Bumi Aksara.

Departemen Pendidikan Nasional. (2002). Manajemen peningkatan mutu berbasis sekolah: Buku I, konsep dasar. Jakarta: Dirjen Dikdasmen, Direktorat Sekolah Lanjutan Tingkat Pertama.

Dwiningrum, S.I.A. (2011). Desentralisasi dan partisipasi masyarakat dalam pendidikan.Yogyakarta: Pustaka Pelajar.

Jaedun, A. (2011). Benchmarking standar mutu pendidikan. Disajikan pada Seminar Nasional Pemanfaatan Hasil Penelitian Penilaian untuk
Peningkatan Mutu Pendidikan, di Hotel Salak, Bogor, Tanggal 26 - 27 Desember 2011. Pusat Penilaian Pendidikan Badan Penelitian dan Pengembangan Kemendikbud.

Mulyasa, E. (2011 ). Manajemen berbasis sekolah konsep, strategi dan implementasi. Bandung: Penerbit Rosda Karya.

Nurkholis. (2003). Manajemen berbasis sekolah: Teori, model dan aplikasi. Jakarta: PT. Grasindo.

Raynolds, L.J. (2005). Kiat sukses manajemen berbasis sekolah. Terjemahan Teguh Budiharso. Jakarta: CV Diva Pustaka.

Rivai, V. \& Murni, S. (2009). Education management. Jakarta: Rajawali Pers.

Robbins, S.P., \& Judge, T.A. (2011). Organizational behavior. New Jersey: Pearson Education.

Rohiat. (2010). Manajemen sekolah teori dasar dan praktik. Bandung: Refika Aditama.

Rosyada, D. (2007). Paradigma pendidikan demokratis: sebuah model pelibatan masyarakat dalam penyelenggaraan pendidikan. Jakarta: Kencana.

Sallis, E. (2010). Total quality management in education. Terjemahan Ahmad Ali Riyadi. Jogjakarta: IRCiSod.

Soedijarto. (2008). Landasan dan arah pendidikan nasional kita. Jakarta: Kompas.

Suryana, S. (2011). Permasalahan mutu pendidikan dalam perspektif pembangunan pendidikan. Jurnal Edukasi, 1(1), 5 - 10. 